\title{
Saving the Empire: The politics of immigrant tuberculosis in Canada
}

\author{
Sylvia Reitmanova
}

\begin{abstract}
"Yet in every continent, under every climate, and among men of every race, there are communities where tuberculosis is either completely absent or of little consequence; in fact, the disease has been practically wiped out from a few localities where it was once prevalent. Clearly, then, its destructive power is not the inevitable expression of geographic, climatic or racial factors."
\end{abstract}

-- René and Jean Dubos (1)

Through the lens of anthropology, health conditions are often embedded in diverse political and economic forces, interests, and discourses that powerfully shape our understanding of health, redefine the ways we think of disease, and challenge the boundaries of what we consider to be objective science (2). However, Western medical science rejects defining disease as a political or cultural construct since it assumes that the human body - which is often seen as a machine (3) - can be objectively described, measured, and evaluated. Disease is understood as a pure consequence of diverse biological, chemical, physical, and mechanical factors (or their combinations) that impact negatively on the human body at its macro- or micro-level. The role of a physician, then, is to take apart the broken machine and to fix or replace the damaged parts (4). As a result of such a conceptualization, disease is defined solely in biological, physical, and chemical terms that are usually neatly organized in the following categories: Definition, Basic Science (Pathogenesis), Epidemiology, Natural

*To whom correspondence should be addressed:

Sylvia Reitmanova

Division of Community Health \& Humanities

Health Sciences Centre

Faculty of Medicine

Memorial University

St. John's, NL, Canada, A1B3V6

Telephone 1709 777-6213

Fax 1709 777-7382

Emailsreitman@mun.ca
History (Spread and Clinical Manifestation), Diagnosis, Treatment, and Prognosis (5).

Following these concepts, tuberculosis (TB) is defined in medical books as an infectious disease caused by a bacillus, Mycobacterium tuberculosis, whose microbiological and chemical properties one can study in great detail. This definition is accompanied by a comprehensive description of the anatomic, pathophysiological, and immunological processes taking place when the TB bacillus settles in a human body, usually followed by the description of the clinical symptoms of TB and the scientifically established ways to diagnose and treat it. Finally, most medical books familiarize the reader with some medical and social conditions linked to immunodeficiency which are associated with the higher spread and development of TB within certain populations or among certain individuals. However, it needs to be noted here that with the advent of vaccination, antibiotics, and advanced technology during the first half of the twentieth century, TB was reconstructed as a medical disease with a social aspect from a previously held concept defining TB as a social disease with a medical aspect $(6,7)$. Consequently, the role of social factors in the conceptualizing of TB was de-emphasized.

Since modern medical science defines TB strictly as an infectious (not a social) disease, current TB management and control policies are guided by the three basic epidemiologic principles underlying the fight against infectious diseases: elimination of the sources of infection, disruption of the transmission process, and reduction of susceptibility in the unexposed population (8). According to current statistical data, immigrants from developing countries account for the highest ratio of TB cases in Canada (9) and are therefore considered the greatest source of infection. In order to eliminate this foreign source of infection and to disrupt further transmission, TB health management and control relies on two main 
interventions: preventing immigration to Canada of any who have active TB, and monitoring and treating those immigrants with latent TB who are already in the country (10). Taking into account the present conceptualizing of TB as an infectious medical disease, these two epidemiologic interventions seem to be scientifically well-justified.

However, interestingly, barring immigrants with TB from entering Canada in order to eliminate the source of infection was not always considered appropriate. Although objective science considers eliminating the source of infection as one of the main strategies in the modern fight against infectious diseases, documentation exists to show that TB once served as a reason to attract infected immigrants to Canada. In 1886, the Canadian Pacific Railway issued a brochure to attract new British immigrants (11). In this document, dozens of Canadian women maintained that their TB improved in Canada after a short time, due to the "exceedingly healthy climate" (12). These lay women's accounts were also officially supported by medical scientists of those times. For instance, Dr. William Hales Hingston of Montreal established that Canadian "dry air and cold winter... [were] decided recuperators of such diseases as consumption" (13). A British physician, Caleb Williams Saleeby, maintained that "the cold and sun of Canada, playing upon the well-fed, produce a splendour of physique, a low rate of disease [TB], an abundant energy of mind, a joie de vivre, or national euphoria" (13).

How could an infectious disease now perceived as a potential danger to the Canadian public and a burden to the Canadian healthcare system (10) play an important role in the country's immigration propaganda 120 years ago? This question cannot be answered by the simple assumption that, in Canada, TB was considered hereditary and Koch's confirmation of its contagiousness was not readily accepted. Attracting British immigrants with TB to Canada was nothing more than a desperate attempt by the British empire to build the new colony in the country that many considered to be the "White Man's Last Opportunity" (13). In this context, TB became conceptualized as a political means to fulfill a British nationalist dream about Canada as a new Saxondom, rather than a highly feared infectious disease that needed to be avoided and contained.

However, this situation changed dramatically at the beginning of the twentieth century when the rates of TB-related deaths and disabilities in Canada became alarmingly high. Moreover, between 1900-1920, the population in Canada grew by $64 \%$, which created great problems such as overcrowding in unventilated and poorly-sanitated urban slums, labour unrest and distrust of immigrant's foreign attitudes and customs (6). In fact, immigrants were frequently suspected and feared "disease breeders," a belief that often led to "campaigns against immigrant-run street markets and fruit stalls, which were condemned as germ-ridden threats to the public health" (14).

These fears encouraged Canadian upper class politicians, physicians, businessmen, and suffragettes to protect the purity and healthiness of Saxondom from "racial poisons" such as TB, alcoholism, and venereal disease which were decimating their race and society (13). The term "racial poisons" was introduced by Saleeby who once, paradoxically, advocated the healing powers of Canadian skies. According to him, all racial poisons had to be eliminated from a society in order to preserve its quality. Saleeby, like other proponents of Galton's biological theory, believed that the predisposition to some diseases, including TB, was inherited along the lines of race and class $(6,13)$. The followers of this new school of thought, called eugenics, were convinced that the poor and immigrants, because their genes were considered to be inferior, suffered from TB and other diseases more readily than the white non-poor classes. Members of non-European races were often deemed infantilized, backward, and less evolved $(13,15)$. For these reasons, the owners of these supposedly inferior genes were exposed to specific measures to ensure that all defective, unassimilable, and unfit people would be eliminated from the "breeding stock" $(6,13)$. The measures applied to immigrants were thus intended to ensure that "Canada would forever remain white, Anglo-Saxon, and Protestant" (16).

The eugenics goal to eliminate TB was believed to be achievable through two means: controlled reproduction and controlled immigration. Eugenists considered that people with TB would bring "poor, feeble, miserable members into the world who would have no strength and vitality" and would fall easy victims to TB (6). For this reason, they opposed marriages of people with TB and pushed for the implementation of birth control. In 1928, their efforts resulted in the proclamation of the Sexual Sterilization Act of Alberta that justified the sterilization of mentally ill, Aboriginal, and immigrant women, all of whom were accused of decimating the desired stock (13). As a result, Canada "has continued to be profoundly and systematically exclusionary and oppressive for many Canadians" for the following four decades until the Act was finally repealed in 1972 (13).

In terms of controlled immigration, it was understood that, in order to protect existing healthy stock, it was necessary to avoid importing those who were unhealthy. This sentiment resonated in the question raised by Dr. John George Adami, former president of the Canadian 
Association for the Prevention of TB and a delegate to the International Congress of Eugenics:

"Is it not better for us in Canada to increase our population by saving our own and making them strong and healthy rather than by spending our national money in bringing in Doukhobors, Galacians, Poles and the depressed peoples of Southern and Eastern Europe?" (17)

Others echoed this view. For instance, Dr. Helen MacMurchy, the first female intern at TorontoGeneral Hospital, stated in her influential third report on infant mortality in 1912:

"After ages will wonder at the stupidity of Government and a people which takes so much trouble to bring in immigrants from every corner of Europe and, for sheer lack of public thought, lets its own Canadian babies die in a quite unnecessary holocaust." (18)

The Canadian upper class believed the solution to these problems to be the improvement of the federal immigration policy; specifically, banning immigrants with TB from Canada. Yet, the facts - such as the lower rate of TB among immigrants compared to the higher rate of TB found among Quebec's factory workers returning home from the United States - continued to be overlooked (6). Bringing in immigrants with TB was no longer seen as a tool to save the Empire. On the contrary, in the first decade of the twentieth century, TB was perceived as an element destroying it. Consequently, immigrants with TB were barred from Canada along with those identified as "idiots, imbeciles, feeble-minded persons, epileptics, alcoholics, criminals, and anarchists" as well as persons who were "insane, dumb, blind, physically defective, and illiterate" (19). The routine chest X-ray examination of immigrants for TB was introduced in 1948 when Dr. George Clair Brink, the director of Ontario's Division of TB Control, inaugurated this program in England by bringing with him a Canadian X-ray machine (20). Around the same time, physicians called for repeated X-rays of immigrants already in Canada for a period of two to three years after their admission date (21).

Routine surveillance of immigrants with diagnosed latent TB infection is currently still required by Canada's immigration law (10). Its critics state, however, that "to date, there is no evidence that tuberculosis among the foreign-born population significantly affects the indigenous population" (22). For instance, a cross-sectional Montreal study has shown that there was no association between TB positivity of non-vaccinated Canadian-born children and neighbourhoods highly populated with immigrants from endemic countries (23). On the contrary, the risk of transmission to immigrant communities was greater since many immigrants had little protection from TB due to their poor living conditions (24). In addition, Fanning calculated that the screening for and prophylactic treatment of all latent infections among immigrants, which some policy makers recommend, would cost Canada about 35 million dollars each year (22).

It is true that immigrants account for $63 \%$ of TB cases in Canada, an increase of 28\% since 1980 (9), but research rarely identifies the poverty of immigrants as the reason for such an unequal distribution of TB in western societies (25). Instead, many public health sources name the country of origin as the main factor associated with an immigrant's higher risk of developing TB $(10,26,27)$. As a result of such an interpretation of risks associated with immigrant TB, these studies recommend that the effectiveness of TB control be enhanced by improving case reporting and adherence to drug therapy rather than by addressing the issue of immigrant poverty. Even the report about newly diagnosed TB cases that Canadian physicians are required to send to the public health authorities does not contain any detailed information on the social determinants of the sufferers' health such as their socioeconomic status, or their employment, life, and work circumstances (10).

Since TB is no longer seen as a social disease, the following facts are easily underrated in the explanation of immigrant TB: In the past two decades, the percentage of immigrant families living below the poverty line in Canada has increased. In 2000, about $20 \%$ of people residing in poor neighbourhoods (physically and economically underdeveloped places with high crime and few amenities) were immigrants (more than double the rates in the general population) and about $35 \%$ of immigrants had lower income in comparison with the general urban population (28). Immigrants, a substantial proportion of the "inner city" population which researchers defined as the "individuals who tend to be on the losing end of inequality issues," faced high unemployment and underemployment, fewer education opportunities, social dysfunction, homelessness, overcrowded or substandard housing, malnutrition, lack of access to health care and services, and substance abuse (28). As a result of these poverty-related conditions, the health status of immigrants has been compromised. They have been found to be at high risk of developing several infectious diseases (29) among which, not surprisingly, is TB (30).

Hay et al. concluded that "social issues appear to explain more about variations in health and well-being than do any combination of individual factors" (28). The concept of blaming people's biological endowment along with their personal health practices for their ill 
health is outdated. The importance of social determinants of health has been recognized in public health for a long time (31). For instance, a Montreal study indicated that immigrants accounted for $77.3 \%$ of TB cases in Montreal between 1992 and 1995 and the majority of these people faced problems such as poverty, homelessness and substance abuse (32). However, public health authorities hesitate to acknowledge that what some immigrants find in this country is poverty, which fosters their vulnerability to TB. For instance, the current edition of Canadian TB Standards acknowledges that socioeconomic factors such as poverty, overcrowding and malnutrition play an important role in the development of TB and therefore they need to be taken into consideration in prevention strategies (10). However, the edition has applied this approach only to the problem of TB among Aboriginal people in Canada. The section on TB management within the immigrant population does not make any reference to immigrant poverty and its relevance to TB. Modern public health policies based on attributing the problem of immigrant TB to the country of origin while overlooking the real social causes that underlie immigrants' health are no better than older health policies that once associated TB with immigrants' "inferior" genes.

One can conclude that a historic account of TB in Canada clearly demonstrates how a disease can transcend its biologically-paved boundaries only to become a political construct in which nationality and ethnic origin interfer with the conceptualization of disease and minimize the role of scientific objectivity. If medical science wants to maintain its principles of objectivity, it needs to assume the responsibility of stopping disease from becoming a political issue. When both medical and non-medical interventions vary across lines of nationality and class, scientific definitions of diseases then become useless. Consequently our narrow-minded focus on geography and nationality as causes of TB in Canada poses a risk of unleashing the destructive power of diseases such as $\mathrm{TB}$ on a vulnerable population.

\section{ACKNOWLEDGMENTS}

The author would like to thank to Dr. Diana L. Gustafson and Dr. Mark Tate for their generous guidance in critical culture theory and Mrs. Irene Sheppard for her kind and patient editing help.

\section{REFERENCES}

1. Dubos RJ, Dubos J. The White Plague. Tuberculosis, Man and Society. London: Victor Gollancz Ltd.; 1953.

2. Good B. Medicine, rationality, and experience: an anthropological perspective. Cambridge; New York: Cambridge
University Press; 1994.

3. McKeown T. Determinants of health. In: Lee PR, Estes CL, editors. The Nation's Health. 5th ed. Boston: Jones \& Bartlett; 1999. p.9-17.

4. Clarke JN. Health, Illness and Medicine in Canada. 4th ed. Toronto, ON: Oxford University Press; 2004.

5. Avery ME, First LR, editors. Pediatric Medicine. 2nd ed. Baltimore, MD: Williams \& Wilkins; 1994.

6. McCuaig K. The Weariness, the Fever, and the Fret. The Campaign against Tuberculosis in Canada 1900-1950. Montreal, Kingston: McGill-Queen's University Press; 1999.

7. Feldberg GD. Disease and class: tuberculosis and the shaping of modern North American society. New Brunswick, N.J.: Rutgers University Press; 1995.

8. Mausner JS, Kramer S. Epidemiology - An Introductory Text. 2nd ed. Philadephia, PA: W.B. Saunders Company; 1985.

9. Public Health Agency Canada. Tuberculosis in Canada 2005 [monograph on the Internet]. Public Health Agency Canada; 2005 [cited 2007 Dec 11]. Available from: www.phacaspc.gc.ca/publicat/tbcan-pre05/pdf/tbcan-pre2005_e.pdf.

10. Public Health Agency Canada. Canadian Tuberculosis Standards [monograph on the Internet]. 6th ed. Public Health Agency Canada; 2007 [cited 2008 Feb 8]. Available from: http://www.phac-aspc.gc.ca/tbpc-latb/pubs/pdf/tbstand07_e.pdf.

11. Hupfer M. Anything in Skirts Stands a Chance: Marketing the Canadian North-West to British Women, 1880-1914. J Macromarketing. 1998;18(1):41-9.

12. Canadian Pacific Railway. What women say of the Canadian North-West. In: Jackel S, editor. A flannel shirt and liberty: British emigrant gentlewomen in the Canadian West, 18801914. Vancouver: University of British Columbia Press; ([1886]. 1982). p. 32-65.

13. Devereux C. Growing a Race. Nellie L. McClung and the Fiction of Eugenic Feminism. Montreal, Kingston: McGillQueen's University Press; 2005.

14. Tomes N. The Making of a Germ Panic, Then and Now. Am J Public Health. 2000;90(2): 191-8.

15. Fernando S. Cultural diversity, mental health and psychiatry. The struggle against racism. East Sussex, UK: Brunner Routledge; 2003.

16. Chapman T. Early Eugenics Movement in Western Canada. Alberta History. 1977;25(4): 9-17.

17. Adami JG. The Modes of Treating Tuberculosis and Their Cost. CAPTAR. 1909;151.

18. Toronto the 'uncivilized' - Bad water, unclean milk and neglect killed many hundreds early in the century. The Toronto Star. 1999 Dec 31; Sect L1.

19. Government of Canada. Eastern Canada. Canada - The New Homeland. Ottawa: Ministry of Immigration and Colonization; 1924.

20. The Lung Association [homepage on the Internet]. Tuberculosis History in Canada. [cited 2007 Nov 28]. Available from: http://www.lung.ca/tb/tbhistory/index.html.

21. Adamson JD, Edmison JN. Immigration Tuberculosis. JCMA. 1947;57(5):432-34.

22. Fanning EA. The impact of global tuberculosis in Canada: We are our brothers' keepers. Can J Infect Dis. 1995;6(5):225-27.

23. Menzies D, Chan CH, Vissandjee B. Impact of immigration on tuberculosis infection among Canadian-born schoolchildren and young adults in Montreal. Am J Respir Crit Care Med. 1997,156(6):1915-21.

24. Carballo M, Divino JJ, Zeric D. Migration and health in the European Union. Trop Med Int Health. 1998;3(12):936-44.

25. Farmer P. Infections and Inequalities. Berkeley, Los Angeles: University of California Press; 1999.

26. Hyman I. Immigration and health. Ottawa: Health Canada; 
2001.

27. Wobeser WL et al. Expanding the epidemiologic profile: risk factors for active tuberculosis in people immigrating to Ontario. CMAJ. 2000;163(7): 823-8.

28. Hay D, Varga-Toth J, Hines E. Frontline Health Care in Canada: Innovations in Delivering Services to Vulnerable Populations [monograph on the Internet]. Canadian Policy Research Networks; 2006 [cited 2007 Dec 5]. Available from: http://www.cprn.com/documents/45652_en.pdf.

29. Hyman I. Immigration and Health: Reviewing Evidence of the Healthy Immigrant Effect in Canada [monograph on the Internet]. CERIS Working Paper \# 55. Joint Centre of Excellence for Research on Immigration and Settlement, Toronto; 2007 [cited 2008 Jul 19]. Available from: http://ceris.metropolis.net/Virtual\%20Library/WKPP\%20List/ WKPP2007/CWP55.pdf

30. Ambrosio E, Baker D, Crowe C, Hardill K. The Street Health Report: A study of the health status and barriers to health care of homeless women and men in the City of Toronto; 1992.

31. Shah CP. Public Health and Preventive Medicine in Canada. 5th ed. Toronto, ON: Elsevier; 2003.

32. Rivest P, Tannenbaum T, and Bedard L. Epidemiology of tuberculosis in Montreal. CMAJ. 1998 Mar;158:605-9.

Sylvia Reitmanova (M.D., M.Sc.Med., Ph.D. 2009) is a PhD Candidate at the Division of Community Health \& Humanities at Memorial University in St. John's, NL. Her research interests include cross-cultural health and education as well as health and social inequalities of marginalized populations. 